\title{
Exposing Differences in Monomer Exchange Rates of Multicomponent Supramolecular Polymers in Water
}

Citation for published version (APA):

Baker, M. B., Gosens, R. P. J., Albertazzi, L., Matsumoto, N. M., Palmans, A. R. A., \& Meijer, E. W. (2016). Exposing Differences in Monomer Exchange Rates of Multicomponent Supramolecular Polymers in Water. Chembiochem, 17(3), 207-213. https://doi.org/10.1002/cbic.201500606

Document status and date:

Published: 02/02/2016

DOI:

10.1002/cbic.201500606

Document Version:

Publisher's PDF, also known as Version of record

\section{Document license:}

Taverne

\section{Please check the document version of this publication:}

- A submitted manuscript is the version of the article upon submission and before peer-review. There can be important differences between the submitted version and the official published version of record.

People interested in the research are advised to contact the author for the final version of the publication, or visit the DOI to the publisher's website.

- The final author version and the galley proof are versions of the publication after peer review.

- The final published version features the final layout of the paper including the volume, issue and page numbers.

Link to publication

\footnotetext{
General rights Owners
rights.

- You may freely distribute the URL identifying the publication in the public portal. please follow below link for the End User Agreement:

www.umlib.nl/taverne-license

Take down policy

If you believe that this document breaches copyright please contact us at:

repository@maastrichtuniversity.nl

providing details and we will investigate your claim.
}

Copyright and moral rights for the publications made accessible in the public portal are retained by the authors and/or other copyright owners and it is a condition of accessing publications that users recognise and abide by the legal requirements associated with these

- Users may download and print one copy of any publication from the public portal for the purpose of private study or research.

- You may not further distribute the material or use it for any profit-making activity or commercial gain

If the publication is distributed under the terms of Article $25 \mathrm{fa}$ of the Dutch Copyright Act, indicated by the "Taverne" license above, 


\title{
Exposing Differences in Monomer Exchange Rates of Multicomponent Supramolecular Polymers in Water
}

\author{
Matthew B. Baker, ${ }^{[a, b]}$ Ronald P. J. Gosens, ${ }^{[a]}{ }^{[a}$ Lorenzo Albertazzi, ${ }^{[a]}$ Nicholas M. Matsumoto, ${ }^{[a]}$ \\ Anja R. A. Palmans, ${ }^{[a]}$ and E. W. Meijer ${ }^{*[a]}$
}

\begin{abstract}
The formation of multicomponent and bioactive supramolecular polymers is a promising strategy for the formation of biomaterials that match the dynamic and responsive nature of biological systems. In order to fully realize the potential of this strategy, knowledge of the location and behavior of bioactive components within the system is crucial. By employing synthetic strategies to create multifunctional monomers, coupled with FRET and STORM techniques, we have investigated the formation and behavior of a bioactive and multicomponent supramolecular polymer. By creating a peptide-dye-monomer conjugate, we were able to measure high degrees of monomer incorporation and to visualize the equal distribution of monomers within the supramolecular polymer. Furthermore, by tracking the movement of monomers, we uncovered small differences in the dynamics of the bioactive monomers.
\end{abstract}

A current challenge for chemists is the creation of systems that are able to match both the organization and the dynamic behavior of biologic systems, such as the extracellular matrix ${ }^{[1-3]}$ or the cellular membrane. ${ }^{[4,5]}$ Supramolecular polymers ${ }^{[, 7]}$ are uniquely suited for this task as a result of their noncovalent and reversible interactions that impart a dynamic and responsive nature to their structures. ${ }^{[8]}$ Akin to natural systems, units of supramolecular polymers have been shown to undergo polymerization/depolymerization, ${ }^{[9,10]}$ monomer exchange, ${ }^{[11]}$ and self-healing ${ }^{[12,13]}$ in both equilibrium and out-of-equilibrium processes. ${ }^{[14]}$

In addition to their dynamic nature, the modularity of supramolecular polymers makes them attractive for utilization in functional biomaterials. ${ }^{[15]}$ One can mix varying amounts of monomers, bioactive or inert, quickly creating custom multicomponent co-polymers with varying mechanical properties and biological activity. ${ }^{[16-20]}$ This approach to supramolecular biomaterials has shown recent success in several peptidic and synthetic systems, whereas recent clinical success ${ }^{[21]}$ offers

[a] Dr. M. B. Baker, R. P. J. Gosens, Dr. L. Albertazzi, Dr. N. M. Matsumoto, Dr. A. R. A. Palmans, Prof. E. W. Meijer

Institute of Complex Molecular Systems

Eindhoven University of Technology

P.O. Box 513, 5600 MB Eindhoven (The Netherlands)

E-mail:e.w.meijer@tue.nl

[b] Dr. M. B. Baker

MERLN Institute for Technology-Inspired Tissue Regeneration

University of Maastricht

P.O. Box 616, 6200 MD Maastricht (The Netherlands)

$\square$ Supporting information for this article is available on the WWW under http://dx.doi.org/10.1002/cbic.201500606. some validation for the approach. Furthermore, gradient assemblies of self-assembling proteins ${ }^{[22]}$ have exhibited an enhanced level of compositional control in the formation of bioactive supramolecular polymers.

Knowledge of the positions and the behavior of the multiple components in such supramolecular polymers is not well established. To improve the rational design of multicomponent supramolecular polymers, it is necessary to know where the functional monomers are, how they affect the supramolecular structure, and how they behave differently from the non-functionalized monomers in the system. Herein we have created a fully synthetic system to visualize and evaluate the incorporation of a model peptide-containing monomer into a supramolecular polymer. Furthermore, we investigated the effect of the model peptide on the kinetics of monomer exchange between supramolecular polymers.

Scheme $1 \mathrm{~A}$ shows the structures of supramolecular monomers used in this study. The previously reported benzene1,3,5-tricarboxamide (BTA)-based ${ }^{[23]}$ water-soluble supramolecular monomers (1), which contain three $\mathrm{C}_{12}-\mathrm{PEG}_{4}$ arms, were used as the base monomeric unit. ${ }^{[2]]}$ These BTAs reliably form multimicron length, one-dimensional supramolecular polymers through hydrophobic and $\mathrm{H}$-bonding interactions in water (micromolar regime), and have been characterized structurally and kinetically. ${ }^{[11,24-26]}$

Orthogonally reactive $A B C$ BTA 2 was designed to allow facile creation of peptide-dye-BTA conjugates. From 2, a RGDSCy5-BTA (3) was envisioned as a suitable model bioactive monomer for this study. In order to compare the incorporation and behavior of $\mathbf{3}$ with that of monomers lacking the highly water-soluble and zwitterionic RGDS, control molecules Cy3BTA (4) and Cy5-BTA (5) were also included in this study.

Shown schematically in Scheme $1 \mathrm{~B}$, multicomponent supramolecular polymers can be formed with varying compositions by mixing small amounts of these labeled and/or bioactive monomers together in a good solvent before injection into water. This procedure has already been validated for the formation of multicomponent BTA polymers containing small amounts $(1-10 \%)$ of dye-BTA conjugates. ${ }^{[11,25,26]}$ Such multicomponent polymers have previously been utilized to exhibit the dynamic nature of these polymers through monomer exchange ${ }^{[11,25]}$ and monomer clustering. ${ }^{[26]}$

The desire to introduce both bioactivity and tracking at separate sites in a single monomer necessitated the creation of an orthogonally reactive BTA (ABC-BTA, 2). Kinetic desymmetrization $^{[27,28]}$ or statistical coupling ${ }^{[29,30]}$ were not realistic strategies for the synthesis of 2; therefore, new strategies that ensured 
A)
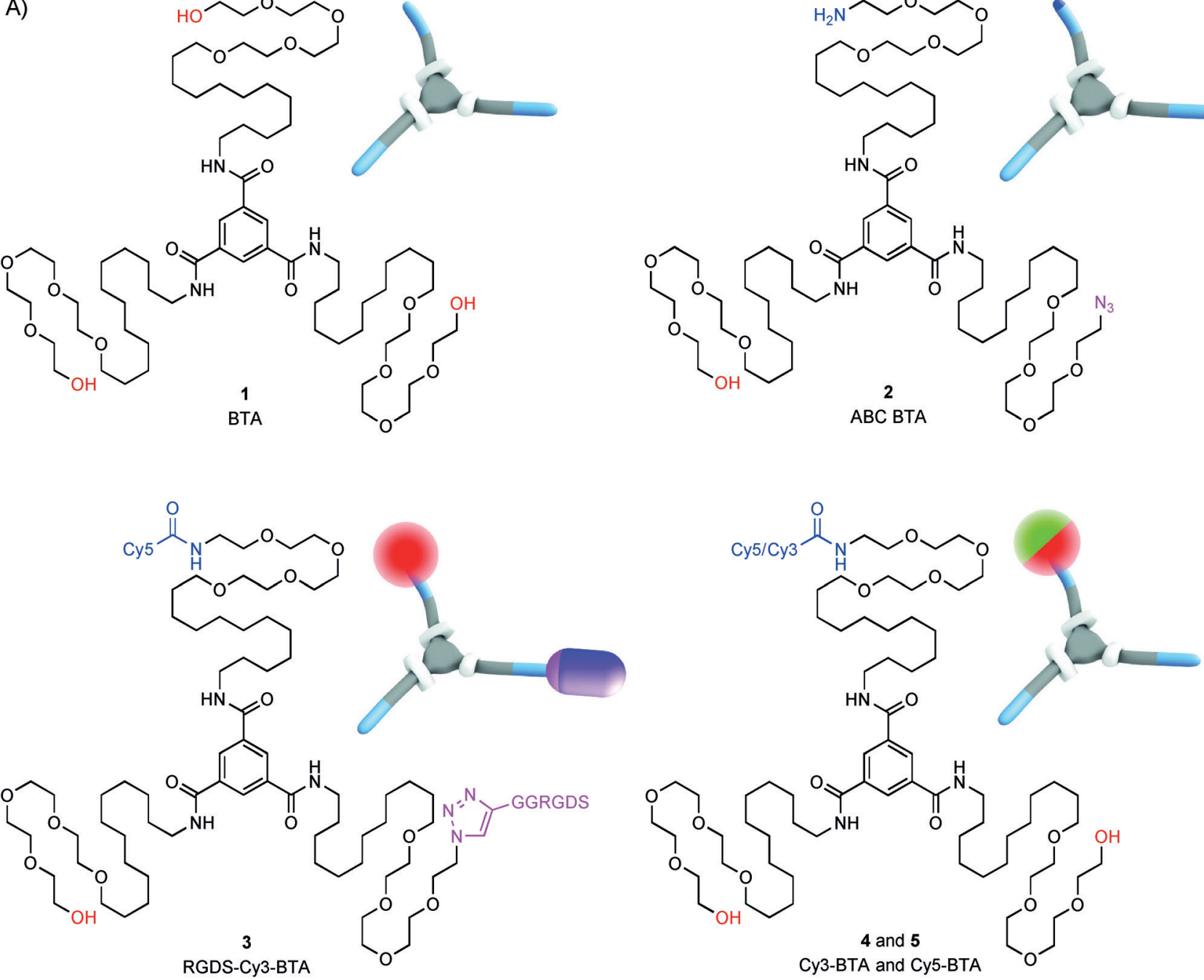

B)

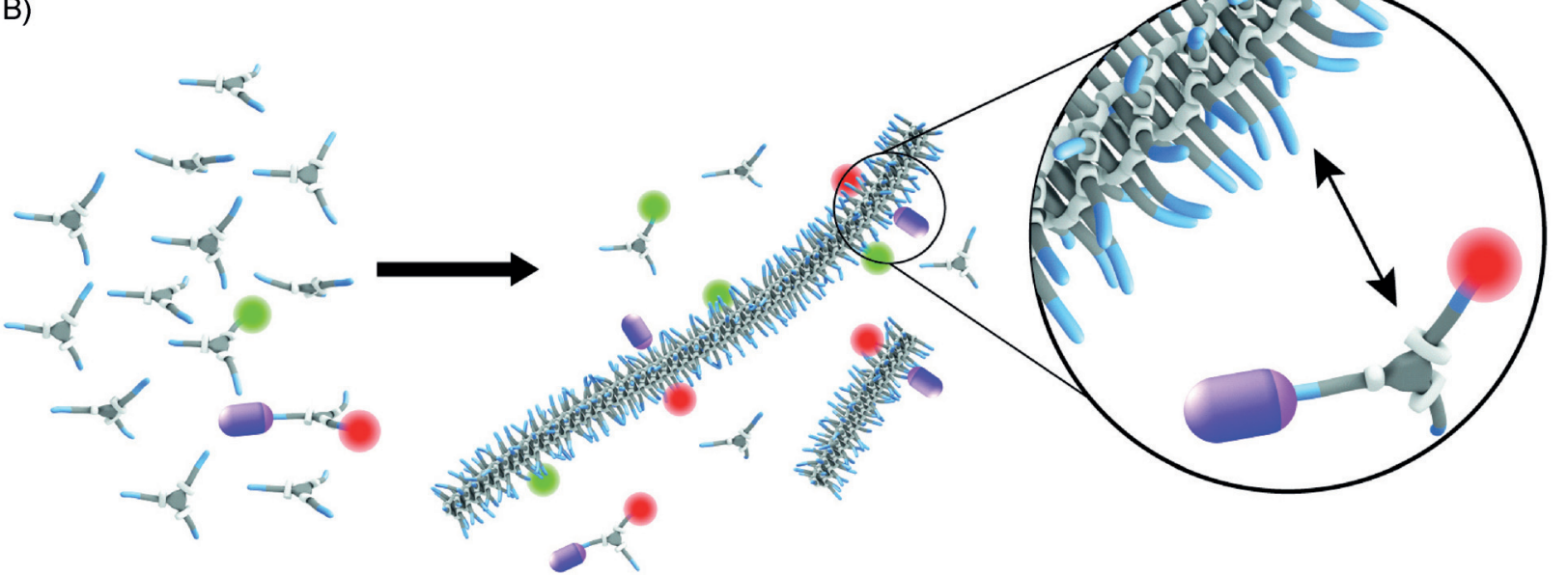

Scheme 1. A) By starting from water-soluble self-assembling BTA 1, desymmetrization of the molecule is employed to form orthogonally reactive synthon 2 (an "ABC BTA"). A dye and a bioactive peptide are attached to separate arms of the BTA core of this molecule to give 3 (RGDS-Cy5-BTA), allowing the tracking of functional monomers within multicomponent supramolecular fibers. These bioactive monomers can easily be compared with non-functionalized dye-labeled BTAs such as 4 (Cy3-BTA). Cyanine3 and Cyanine5 dyes were used as analogues of Cy3 and Cy5 (see the Supporting Information). B) Multicomponent BTA fibers with different functionalities can be formed by employing a modular mixing and dilution strategy. 
the utility of intermediates coupled with high-yielding reactions were designed. Three routes were investigated: 1) desymmetrization of a diazide of type 9,2 ) desymmetrization of symmetric BTA 1, and 3) desymmetrization of a monoazide BTA. ${ }^{[11]}$ Route 1 (Scheme 2) is presented here; details on route 2 and the poorly performing route 3 are presented in the Supporting Information (Schemes S1 and S2).

Route 1 was designed with a late-stage desymmetrization capable of providing useful side products. With desymmetrized trimesic acid monomethyl ester $\mathbf{6}$ serving as starting material, activation of the remaining benzoic acid groups with oxalyl chloride and coupling to an azide-terminated side arm $\left(\mathrm{NH}_{2}^{-}\right.$
$\left.\mathrm{C}_{12}-\mathrm{PEG}_{4}-\mathrm{N}_{3}\right)^{[26]}$ afforded intermediate 7 in good yield. Hydrolysis of the aromatic methyl ester with $\mathrm{LiOH}$ allowed selective 4-(4,6-dimethoxy-1,3,5-triazin-2-yl)-4-methylmorpholinium chloride (DMT-MM) ${ }^{[31,32]}$ coupling between 8 and an alcohol-terminated side arm $\left(\mathrm{NH}_{2}-\mathrm{C}_{12}-\mathrm{PEG}_{4}-\mathrm{OH}, \mathrm{S} 10\right)$ to afford key diazide BTA 9. A statistical Staudinger reduction ${ }^{[33]}$ afforded ABC BTA 2 in $47 \%$ yield. Conveniently, starting diazide 9 could easily be recovered, and the useful diamine BTA 10 was produced in $22 \%$ yield.

From ABC BTA 2, production of RGDS-Cy5-BTA was accomplished in a straightforward manner (Scheme 3). Attachment of a NHS-Cy5 dye, followed by an optimized azide-alkyne cou-<smiles>COC(=O)c1cc(C(=O)O)cc(C(=O)O)c1</smiles>

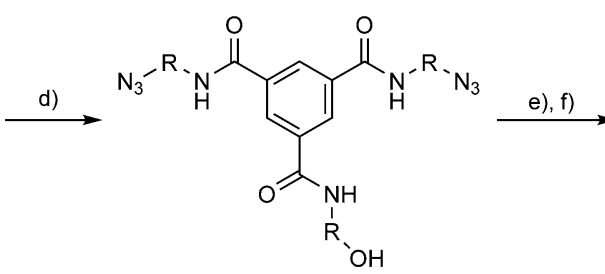<smiles>[R]NPNC(=O)c1cc(C(=O)N[R]N)cc(C(=O)OC)c1</smiles>

7<smiles>[R]PNC(=O)c1cc(C(=O)NP)cc(C(=O)NPN)c1</smiles>

ABC BTA<smiles>[R]NPNC(=O)c1cc(C(=O)O)cc(C(=O)NPN)c1</smiles><smiles>C=CCOC(C)(C)CC(C)(C)C(C)(C)C</smiles>

8<smiles>[R]PNC(=O)c1cc(C(=O)NP)cc(C(=O)NPN)c1</smiles>

10

Scheme 2. Route to $A B C$ BTA 2 via a diazide intermediate. a) oxalyl chloride, $D M F, T H F, 0^{\circ} \mathrm{C}, 3 \mathrm{~h}$; b) 2,2 equiv $\mathrm{H}_{2} \mathrm{~N}-\mathrm{R}-\mathrm{N}_{3}, \mathrm{DIPEA}, \mathrm{CH}_{2} \mathrm{Cl}_{2}, \mathrm{RT}$, overnight (93\%); c) $\mathrm{LiOH}, \mathrm{MeOH}, \mathrm{RT}$, overnight (92\%); d) $\mathrm{H}_{2} \mathrm{~N}-\mathrm{R}-\mathrm{OH}, \mathrm{DMT}-\mathrm{MM}, \mathrm{DMF}, 40^{\circ} \mathrm{C}(75 \%)$; e) $\mathrm{PPh}_{3}, 48 \mathrm{~h}$; f) $\mathrm{H}_{2} \mathrm{O}, 24 \mathrm{~h}$ in $\mathrm{THF}, 40^{\circ} \mathrm{C}(47 \%)$.<smiles>[R]NPNC(=O)c1cc(C(=O)NP)cc(C(=O)NPN)c1</smiles>

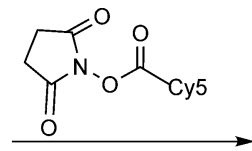

a)<smiles></smiles><smiles>[O]</smiles><smiles>CCCOCC</smiles><smiles>NNPC(=O)c1cc(C(=O)NPO)cc(C(=O)NPNC(=O)C2CCCCC2)c1</smiles><smiles>C#CCC(N)C(=O)OCCOC</smiles>

11

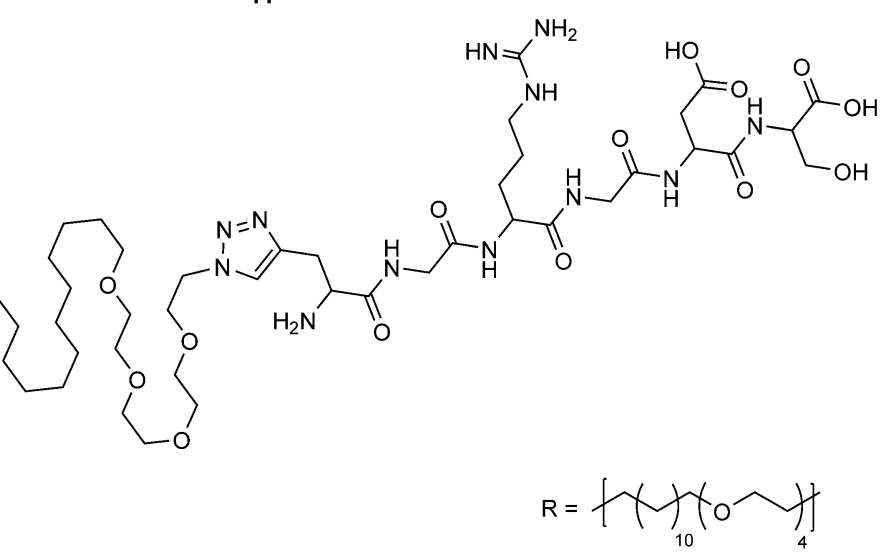

3

RGDS-Cy5-BTA

Scheme 3. A straightforward two-step synthesis of a dye-labeled and peptide-functionalized BTA monomer. a) DMF, RT, 48h (90\%); b) CuSO 4 , NaAsc, BimPy ${ }_{2}$ aminoguanidine, DMF/ $\mathrm{H}_{2} \mathrm{O}(80: 20), \mathrm{RT}, 36 \mathrm{~h}(90 \%)$. 
pling (see the Supporting Information for more details) ${ }^{[34,35]}$ of alkyne-terminated RGDS produced $\mathbf{3}$ in high yield. Within 3, a simple integrin binding motif ${ }^{[36]}$ (RGDS) introduces bioactivity, while Cy5 is employed as a robust tracking dye. The synthesis of $\mathbf{3}$ was designed to be straightforward and general; various peptides could be conjugated through azide-alkyne cycloaddition, whereas simple amine/NHS ester chemistry can ligate commercially available dyes.

With the successful synthesis of the peptide-dye-BTA conjugate 3 (RGDS-Cy5-BTA), a small library of supramolecular polymers was generated to investigate the effect of introducing the peptidic cargo. Two major questions arose: 1) do these peptide-functionalized monomers reliably incorporate into BTA fibers, and 2) is the dynamic behavior of the peptide-labeled monomers altered?

Both questions were investigated with FRET and stochastic optical reconstruction microscopy (STORM) assays. ${ }^{[3]}$ The results and discussion are separated according to whether the measurements were static or dynamic in order to address each question separately. In the following experiments, production of all samples was effected in a standard mix and dilute procedure (see the Supporting Information for more details) for a working solution of supramolecular polymers containing $10 \mu \mathrm{M}$ BTA and 5\% (500 nм) dye labeling in deionized water.

We initially investigated the co-localization of model compounds by use of a FRET-based assay. Depicted in Figure $1 \mathrm{~A}$ and $1 \mathrm{~B}$, the ability of different molecules bearing a Cy5 dye (FRET acceptor) to incorporate with Cy3-BTA (4, FRET donor) into a supramolecular polymer was measured. Co-localization should result in high FRET efficiency $\left(\lambda_{\mathrm{em}} \approx 670 \mathrm{~nm}\right)$, whereas poor incorporation should result in little to no signal. As shown in Figure 1C, supramolecular polymers co-assembled with a water-soluble Cy5 showed only a weak FRET signal (blue line), whereas samples assembled with Cy5-BTA (5) showed high levels of FRET (red line), indicating high co-localization. Surprisingly, the RGDS-Cy5-BTA (3) FRET signal is nearly that of Cy5-BTA (5), thus supporting the conjecture of high levels of incorporation of the peptide-functionalized construct into the supramolecular polymer.
A)

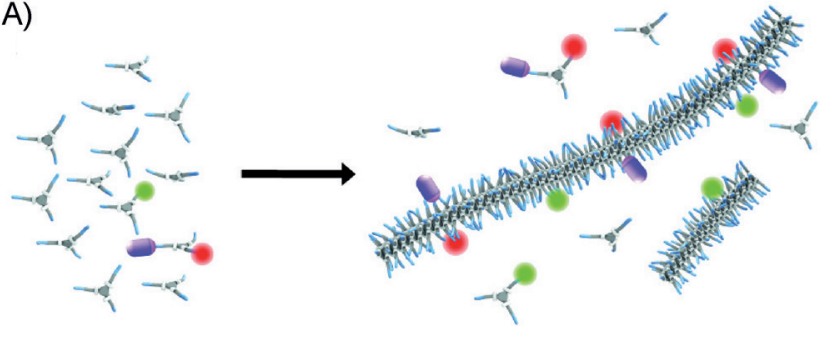

B)

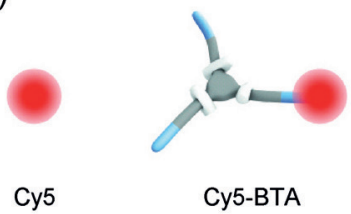

(5)

C)

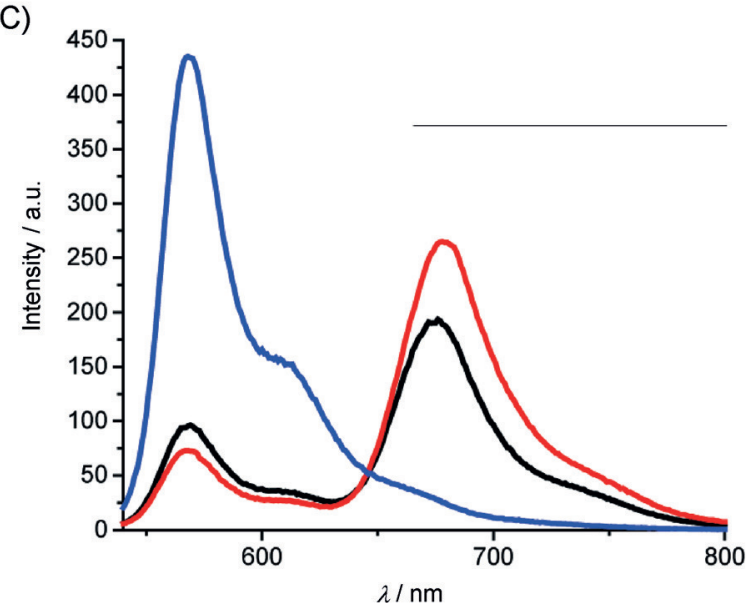

D)
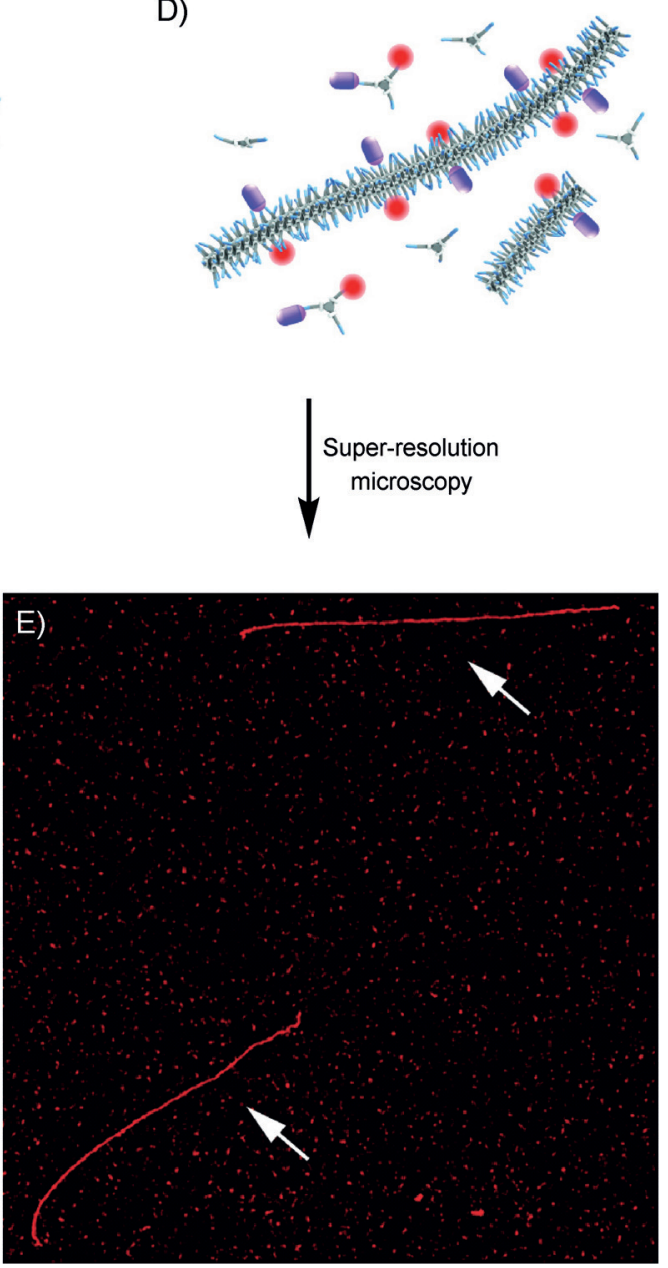

Figure 1. Static measurements. A) Co-assembly of fibers labeled with a FRET donor and B) various FRET acceptor molecules allows determination of co-localization. C) Strong FRET signals are observed both for Cy5-BTA $(\longrightarrow$ ) and for RGDS-Cy5-BTA ( $\longrightarrow$ ), whereas a water-soluble Cy5 (-) analogue shows almost no FRET. D) Assembly of fibers with RGDS-Cy5-BTA monomers and E) visualization with STORM microscopy reveals micron-length individual fibers with a diameter below the resolution of the technique. The STORM image is $21 \times 21 \mu \mathrm{m}$. These samples contain $10 \mu \mathrm{M}$ BTA and $5 \%$ (500 nM) dye labeling in deionized water. 
The Cy5 label can also be used for super-resolution microscopy (STORM). ${ }^{[11,37]}$ In this technique, the positions of the dyelabeled monomers in the supramolecular polymer are directly imaged. As can be seen in Figure $1 \mathrm{D}$, the polymers made with RGDS-Cy5-BTA (3) show the presence of multiple-micronlength supramolecular polymers with a diameter below the resolution of the technique. The fibers are well reconstructed; this implies that the peptide does not induce any clustering or uneven distributions along the length of the polymer. Furthermore, these peptide-functionalized polymers are similar (persistence length, contour length) to the native supramolecular polymers (see the Supporting Information). ${ }^{[11,24,25]}$

The above results clearly show the formation of biofunctionalized BTA supramolecular polymers. The peptide cargo of RGDS-Cy5-BTA (3) does not appear to greatly hinder monomer incorporation; it neither induces clustering, nor greatly affects the form factor of the supramolecular polymers. This high degree of incorporation is crucial to the potential use of these materials in biological settings, in which free peptide monomers in solution can lead to interfering effects by, for example, blocking integrin receptors.
Secondly, we investigated the dynamics of these monomers within the multicomponent assemblies. Shown schematically in Figure 2, the kinetics of exchange can be tracked by mixing multicomponent polymers labeled with different dyes. Again by utilizing Cy3 and Cy5 as a FRET pair, the co-localization of monomers, enabled through exchange between the two initial populations, can be followed by the changes in FRET intensity over time.

In the plot shown in Figure $2 \mathrm{~B}$, the monomer exchange between RGDS-Cy5-BTA (3) and Cy3-BTA (4) polymers is compared with the exchange of Cy5-BTA (5) and Cy3-BTA (4) polymers. In both cases, the FRET exchange over time (Figure 2B) shows curves that gradually approach an equilibrium state that is not fully plateaued even after $10 \mathrm{~h}$. Qualitatively, the curves follow the same kinetic profile, yet the system without the RGDS peptide approaches slightly higher FRET ratios (Figure 1C). Fitting the curves give similar time constants (see the Supporting Information), thus indicating that the kinetics between the two systems are similar when the ensemble of polymers is observed. The similarity in monomer exchange rates in this study stands out in the light of previous findings in which

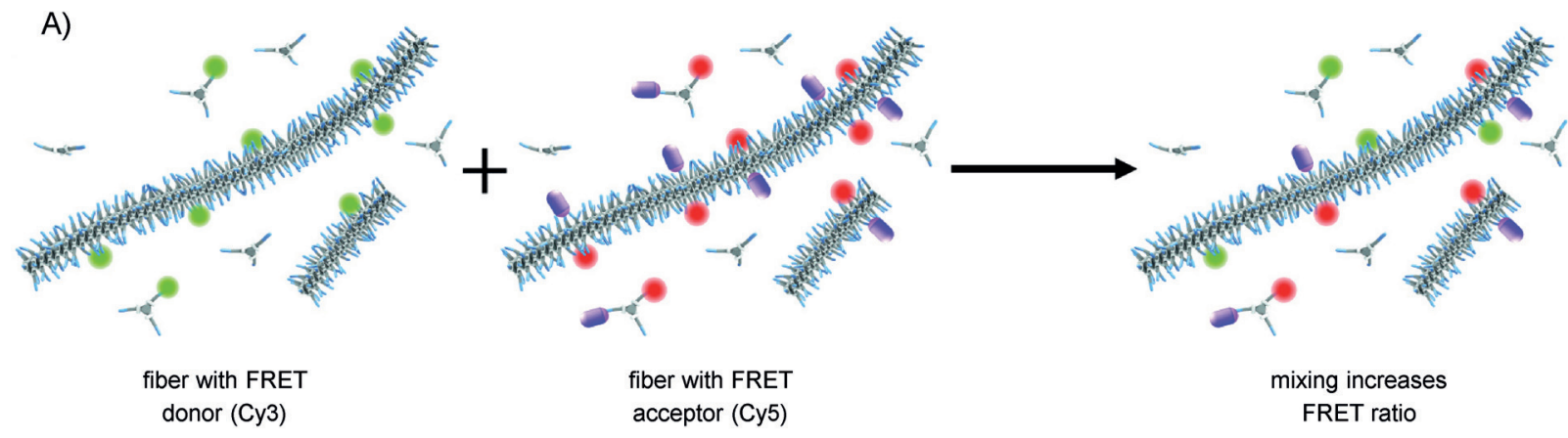

B)

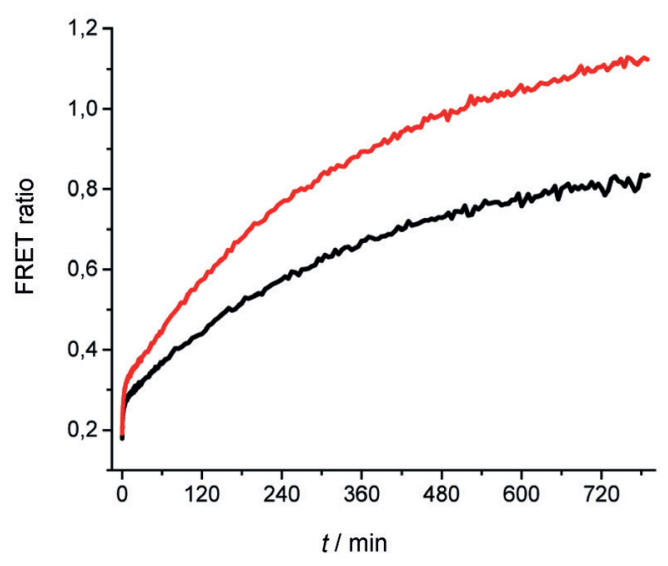

C)

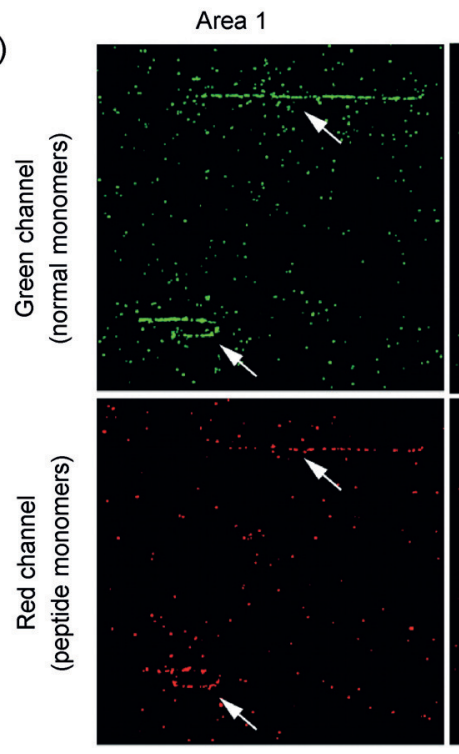

Area 2

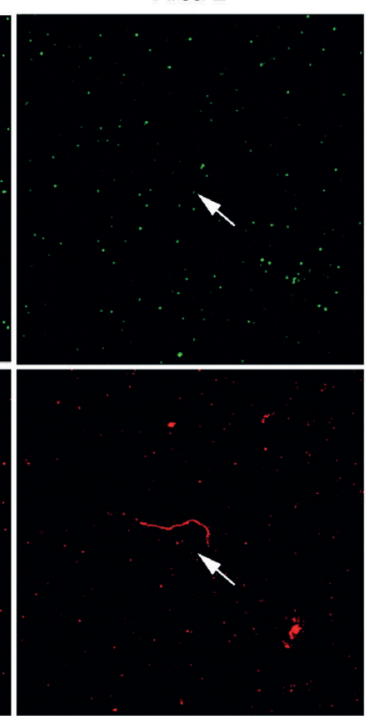

Figure 2. Dynamic measurements. A) Mixing two samples assembled with complementary dyes and tracking the proximity or position of the dyes reveals the dynamics of monomer exchange. B) FRET intensity over time $\left(20^{\circ} \mathrm{C}\right)$ shows similar kinetics of monomer exchange between RGDS-Cy5-BTA and Cy3-BTA fibers $(-)$ and between Cy5-BTA and Cy3-BTA fibers ( $(-)$. C) However, STORM imaging of individual fibers reveals critical differences in the dynamics of the Cy3BTA (4, green) and RGDS-Cy5-BTA (5, red) monomers (see the Supporting Information for further images). The STORM images are $21 \times 21 \mu$ m. These samples contain $10 \mu \mathrm{M}$ BTA and $5 \%(500 \mathrm{~nm})$ dye labeling in deionized water. 
the addition of a chiral directing group significantly slowed the exchange kinetics. ${ }^{[25]}$

Imaging this exchange process with super-resolution microscopy (STORM) not only confirms the timescale of these results, but also provides key additional information (Figure $2 \mathrm{C}$ ). The exchange of Cy3-BTA and Cy5-BTA monomers has previously been shown to proceed at similar rates; however, when we investigated the exchange between Cy3-BTA and RGDS-Cy5-BTA monomers, discernable differences were apparent. At the early time points $(<10 \mathrm{~min})$, green $(\mathrm{Cy} 3-\mathrm{BTA}, 4)$ fibers were consistently observed with a small amount of red (RGDS-Cy5-BTA, 3) present; however, red fibers had no trace of green monomers. This visually shows that the peptide-containing BTA monomers are significantly faster in early exchange than their peptidefree counterparts. One can also see that the exchange of the monomers along the fiber remains random, as previously shown. ${ }^{[11]}$

From the two-color STORM images, there is visual evidence that the peptide-containing monomers are more promiscuous in the early stages of exchange. This result is impossible to predict on the basis of the previous FRET measurements. Because of the previous observation ${ }^{[11]}$ of similar exchange rates between Cy3-BTA (4) and Cy5-BTA (5), this difference is attributed directly to the presence of the RGDS peptide. Presumably, the enhanced water solubility (resulting in a slightly higher free monomer concentration) or the destabilization of the assembly (proximity of charged peptide) gives rise to this phenomenon. The origin of this observed kinetic difference is currently under investigation.

We have shown through proximity-based measurements and microscopy that simple peptide-functionalized BTA monomers readily incorporate into BTA fibers and do not greatly affect the general fiber morphology. This result gives confidence in the application and use of biofunctionalized BTA supramolecular materials. Furthermore, we have produced direct evidence that the peptide-functionalized monomers show a preference for faster initial monomer exchange between supramolecular fibers. Future studies involving a small library of peptides and/or proteins will begin to uncover the generality and scope of these initial observations.

The tracking and location of specific functional monomers (or units) within dynamic supramolecular systems is becoming increasingly important as the research community moves towards more complex and multicomponent materials. If the locations of the introduced monomers are not known and tracked, their effects on the system and its surroundings cannot be accurately discerned. With the system created in this study, future efforts will focus on localizing and imaging the interaction of bioactive supramolecular monomers with

cell surface receptors.

\section{Acknowledgements}

The authors would like to thank Dr. Stanislav Presolski both for discussions and for ligands leading to the optimization of the click coupling protocol. This work was financially supported by the Dutch Ministry of Education, Culture and Science (Gravity program 024.001.035) and the European Research Council (FP7/ 2007-2013, ERC Grant Agreement 246829).

Keywords: biological activity - copolymerization - dynamics peptides $\cdot$ self-assembly

[1] S. H. Kim, J. Turnbull, S. Guimond, J. Endocrinol. 2011, 209, 139-151.

[2] T. Rozario, D. W. DeSimone, Dev. Biol. 2010, 341, 126-140.

[3] J. K. Mouw, G. Ou, V. M. Weaver, Nat. Rev. Mol. Cell Biol. 2014, 15, 771 785.

[4] S. Sonnino, A. Prinetti, Curr. Med. Chem. 2013, 20, 4-21.

[5] G. Vereb, J. Szöllosi, J. Matkó, P. Nagy, T. Farkas, L. Vigh, L. Mátyus, T. A. Waldmann, S. Damjanovich, Proc. Natl. Acad. Sci. USA 2003, 100, $8053-$ 8058.

[6] L. Yang, X. Tan, Z. Wang, X. Zhang, Chem. Rev. 2015, 115, 7169-7239.

[7] T. Aida, E. W. Meijer, S. I. Stupp, Science 2012, 335, 813-817.

[8] J.-M. Lehn, Prog. Polym. Sci. 2005, 30, 814-831.

[9] P. A. Korevaar, S. J. George, A. J. Markvoort, M. M. J. Smulders, P. A. J. Hilbers, A. P. H. J. Schenning, T. F. A. De Greef, E. W. Meijer, Nature 2012, $481,492-496$.

[10] S. Ogi, K. Sugiyasu, S. Manna, S. Samitsu, M. Takeuchi, Nat. Chem. 2014, 6, $188-195$

[11] L. Albertazzi, D. van der Zwaag, C. M. A. Leenders, R. Fitzner, R. W. van der Hofstad, E. W. Meijer, Science 2014, 344, $491-495$.

[12] K. Miyamae, M. Nakahata, Y. Takashima, A. Harada, Angew. Chem. Int. Ed. 2015, 54, 8984-8987; Angew. Chem. 2015, 127, 9112-9115.

[13] P. Cordier, F. Tournilhac, C. Soulié-Ziakovic, L. Leibler, Nature 2008, 451, 977-980.

[14] J. Boekhoven, A. M. Brizard, K. N. K. Kowlgi, G. J. M. Koper, R. Eelkema, J. H. van Esch, Angew. Chem. Int. Ed. 2010, 49, 4825-4828; Angew. Chem. 2010, 122, 4935-4938.

[15] R. Dong, Y. Zhou, X. Huang, X. Zhu, Y. Lu, J. Shen, Adv. Mater. 2015, 27, $498-526$.

[16] K. Petkau-Milroy, M. H. Sonntag, A. H. A. M. Van Onzen, L. Brunsveld, J. Am. Chem. Soc. 2012, 134, 8086-8089.

[17] J. Z. Gasiorowski, J. H. Collier, Biomacromolecules 2011, 12, 3549-3558.

[18] P. Y. W. Dankers, M. C. Harmsen, L. A. Brouwer, M. J. A. van Luyn, E. W. Meijer, Nat. Mater. 2005, 4, 568-574.

[19] S. S. Lee, E. L. Hsu, M. Mendoza, J. Ghodasra, M. S. Nickoli, A. Ashtekar, M. Polavarapu, J. Babu, R. M. Riaz, J. D. Nicolas, D. Nelson, S. Z. Hashmi, S. R. Kaltz, J. S. Earhart, B. R. Merk, J. S. McKee, S. F. Bairstow, R. N. Shah, W. K. Hsu, S. I. Stupp, Adv. Healthcare Mater. 2015, 4, 131-141.

[20] J.-M. Lehn, Angew. Chem. Int. Ed. 2015, 54, 3276-3289; Angew. Chem. 2015, 127, 3326-3340.

[21] D. Castle, Xeltis Completes First-Ever Study of Endogenous Tissue Growth Technology, 2015 (http://www.xeltis.com/wp-content/uploads/2015-0519-Xeltis-Successful-feasibility-ENG).

[22] G. A. Hudalla, T. Sun, J. Z. Gasiorowski, H. Han, Y. F. Tian, A. S. Chong, J. H. Collier, Nat. Mater. 2014, 13, 829-836.

[23] S. Cantekin, T. F. A. de Greef, A. R. A. Palmans, Chem. Soc. Rev. 2012, 41, 6125-6137.

[24] C. M. A. Leenders, L. Albertazzi, T. Mes, M. M. E. Koenigs, A. R. A. Palmans, E. W. Meijer, Chem. Commun. 2013, 49, 1963-1965.

[25] M. B. Baker, L. Albertazzi, I. K. Voets, C. M. A. Leenders, A. R. A. Palmans, G. M. Pavan, E. W. Meijer, Nat. Commun. 2015, 6, 6234.

[26] L. Albertazzi, F. J. Martinez-Veracoechea, C. M. A. Leenders, I. K. Voets, D. Frenkel, E. W. Meijer, Proc. Natl. Acad. Sci. USA 2013, 110, 12203-12208.

[27] M. B. Baker, I. Ghiviriga, R. K. Castellano, Chem. Sci. 2012, 3, 1095- 1099.

[28] C. Chen, R. Dagnino, Jr., J. R. McCarthy, J. Org. Chem. 1995, 60, $8428-$ 8430 . 
[29] P. J. M. Stals, J. F. Haveman, A. R. A. Palmans, A. P. H. J. Schenning, J. Chem. Educ. 2009, 86, 230-233.

[30] D. Türp, T.-T.-T. Nguyen, M. Baumgarten, K. Müllen, New J. Chem. 2012 36, $282-298$.

[31] M. Kunishima, C. Kawachi, J. Morita, K. Terao, F. Iwasaki, S. Tani, Tetrahedron 1999, 55, 13159-13170.

[32] M. Kunishima, C. Kawachi, K. Hioki, K. Terao, S. Tani, Tetrahedron 2001 , 57, $1551-1558$.

[33] Y. G. Gololobov, I. N. Zhmurova, L. F. Kasukhin, Tetrahedron 1981, 37, $437-472$.
[34] H. C. Kolb, M. G. Finn, K. B. Sharpless, Angew. Chem. Int. Ed. 2001, 40, 2004-2021; Angew. Chem. 2001, 113, 2056-2075.

[35] S. I. Presolski, V. Hong, S.-H. Cho, M. G. Finn, J. Am. Chem. Soc. 2010 $132,14570-14576$.

[36] M. D. Pierschbacher, E. Ruoslahti, Nature 1984, 309, 30-33.

[37] M. J. Rust, M. Bates, X. Zhuang, Nat. Methods 2006, 3, 793-795.

Manuscript received: October 13, 2015

Accepted article published: November 25, 2015

Final article published: December 23, 2015 